\title{
CORPORATE SOCIAL RESPONSIBILITY \\ DAN PEMBERDAYAAN MASYARAKAT \\ (Studi Komparatif Bank Syariah dan Bank Konvensional)
}

\author{
Sufyati HS \\ Dosen Universitas Nasional Jakarta
}

\begin{abstract}
Abstrak
Penelitian ini menyimpulkan bahwa terdapat perbedaan dampak Corporate Social Responsibility/CSR bank syariah dan bank konvensional terhadap pemberdayaan masyarakat. Dari tiga variabel yang diujikan meliputi variabel ekonomi, sosial dan lingkungan yang diukur secara terpisah, ternyata variabel ekonomi pada bank konvensional tidak memiliki dampak, sedangkan variabel sosial dan lingkungan memiliki dampak terhadap pemberdayaan masyarakat. Temuan ini mengindikasikan bahwa program CSR bank konvensional tidak murni berperan dalam pemberdayaan ekonomi masyarakat, tapi lebih kearah bisnis komersil dan keberpihakan kepada pelaku usaha yang lebih feasible. Program CSR bidang ekonomi yang dijalankannya dengan model pola kemitraan yang berujung pemberian fasilitas pinjaman dengan tingkat suku bunga dan persyaratan tertentu sehingga memberatkan masyarakat.Sebaliknya, CSR bank syariah lebih berdampak pada pemberdayaan ekonomi masyarakat, karena dibarengi dengan pembinaan dan pengembangan ekonomi umat. Program yang dilakukannya melalui penyaluran produk kredit kebajikan (qard hasan), yaitu pinjaman tanpa margin (bagi hasil) yang diberikan secara perorangan dan kelompok.

Penelitian ini sependapat dengan penelitian yang dilakukan oleh Sayd Farook, et al (2011), Al-Qadi (2012), Yazis, et al (2013), Chintaman (2014), dan Ershad (2015), bahwa bank syariah menerapkan aspek tanggung jawab sosial dalam semua dimensi, sedangkan bank konvensional lebih pada dimensi sosial dan lingkungan. Sependapat pula dengan teori Elkington (1999), Jim Ife, et al (2006), Chahal, et al (2006), dan David Crawther (2008), yang mengatakan bahwa dalam pemberdayaan masyarakat hendaklah disertai transformasi secara seimbang, baik itu transformasi ekonomi,
\end{abstract}


sosial, lingkungan, budaya dan agama maupun politik, sehingga kekuatan faktor-faktor itu akan membentuk kemandirian masyarakat.

Sebaliknya, penelitian ini tidak sependapat dengan teori Milton Friedman (1962), Joel Bakan (1970) dan Thurow (1997), bahwa tanggung jawab sosial perusahaan hanyalah memaksimumkan profit dan bila perusahaan melaksanakan CSR akan menurunkan profit.Tanggung jawab sosial hanya ada pada individu dan tidak melekat pada perusahaan, sebab tanggung jawab perusahaan adalah menghasilkan keuntungan sebesar-besarnya bagi pemegang saham.

Penelitian ini menggunakan metode kualitatif dan kuantitatif. Data primer meliputi hasil observasi, wawancara dan penyebaran angket. Data sekunder meliputi buku, jurnal, artikel, laporan tahunan perusahaan dan sumber lainnya yang relevan dengan topik penelitian ini. Penelitian ini menggunakan pendekatan ekonomi dengan teknik analisis data multiple linear regression.

Kata kunci : Social Responsibility, Pemberdayaan Masyarakat, Bank Syariah, Bank Konvensional

\section{A. PENDAHULUAN}

Pembangunan suatu negara tidak hanya menjadi tanggung jawab pemerintah, tetapi juga menjadi tanggung jawab sektor swasta dan masyarakat. Perusahaan merupakan bagian dari pilar perekonomian suatu negara yang harus berperan aktif dalam pembangunan masyarakat. Dalam tatanan realita, banyak perusahaan yang sudah menjalankan aktivitas tanggung jawab sosial perusahaan at au populer dengan istilah corporate social responsibility (selanjutnya disebut CSR) ${ }^{38}$ di tengah masyarakat yang hasilnya dapat dirasakan

${ }^{38}$ Jika dilihat dari asal katanya, CSR berasal dari literatur etika bisnis di Amerika Serikat, dikenal sebagai corporate social responsibility atau social responsibility of corporation. Kata corporation atau perusahaan telah dipakai dalam bahasa Indonesia yang diartikan sebagai perusahaan, khususnya perusahaan besar. Kata "perusahaan" berasal dari bahasa Latin "corpus/corpora" yang berarti badan, dan sebetulnya berarti "yang dijadikan suatu badan". Jika ditelusuri, pada mulanya korporasi justru tidak menunjukkan organisasi yang mencari untung. Kees Berteens: Pengantar Etika Bisnis, Seri Filsafat Atmajaya : 21, (Yogyakarta: Kanisius, 2000), 289. Dari sisi etimologis CSR kerap diterjemahkan sebagai tanggung jawab sosial perusahaan, sedangkan dari sisi terminologis CSR diartikan sebagai tanggung jawab perusahaan kepada para pemangku kepentingan untuk berlaku etis, meminimalkan dampak negatif yang mencakup aspek ekonomi sosial dan lingkungan (triple bottom

INDO-ISLAMIKA, Volume 6 No.1 Januari - Juni 2016/1438 I 23 
langsung oleh masyarakat. Tapi, kenyataannya masih banyak perusahaan yang ragu dan belum menjalankan program CSR secara optimal.

Pada mulanya CSR masih bersifat sukarela (philantrophy), berlanjut menjadi sebuah tanggung jawab yang diwajibkan. ${ }^{39}$ Pemerintah melalui kebijakannya mengeluarkan undang-undang No 40 tahun 2007 yang intinya mewajibkan setiap perusahaan untuk melaksanakan tanggung jawab sosial perusahaan. ${ }^{40}$

CSR sebenarnya merupakan bagian dari strategi bisnis jangka panjang dalam sebuah korporasi, ${ }^{41}$ bukan hanya sekedar biaya, melainkan adalah investasi jangka panjang yang menguntungkan perusahaan. CSR sebagai investasi sosial (social investment) korporasi, ikut berkontribusi dalam memberdayakan masyarakat (community empowerment), sehingga mampu memenuhi kebutuhan/hak dasar, serta memanfaatkan sumber daya dan peluang ekonomi secara bertanggung jawab dan berkelanjutan. ${ }^{42}$

Pada bank syariah pelaksanaan CSR seyogyanya lebih baik dari pada bank konvensional. Bank syariah belum mempertimbangkan dimensi sosial yang terkait dengan pembangunan, yang merupakan esensi penting dalam moral ekonomi Islam, masih adanya kesenjangan antara aspirasi dan realitas. ${ }^{43}$ Dari sudut dimensi

line) dalam rangka mencapai tujuan pembangunan berkelanjutan.Yusuf Wibisono, Membedah konsep dan Aplikasi CSR (Gresik: Fascho Publishing, 2007), 8. Lihat juga William C. Frederick, et al. Business And Society, Corporate Strategy, Public Policy, Ethics (Pensylvania State University: McGraw-Will,1988), 626.

${ }^{39}$ Hendrik Budi Untung, Corporate Social Responsibility (Jakarta: Sinar Grafika, 2008), 89.

${ }^{40}$ Undang-Undang No. 40 Tahun 2007 Tentang Perseroan Terbatas, Pasal 74 ayat 1 Perseroan yang menjalankan kegiatan usahanya di bidang dan/atau berkaitan dengan sumber daya alam wajib melaksanakan Tanggung Jawab Sosial dan Lingkungan. Ayat 2 Tanggung Jawab Sosial dan Lingkungan sebagaimana dimaksud pada ayat (1) merupakan kewajiban Perseroan yang dianggarkan dan diperhitungkan sebagai biaya Perseroan yang pelaksanaannya dilakukan dengan memperhatikan kepatutan dan kewajaran.

${ }^{41}$ Frits R Dimu Heo, CSR Menu Wajib Perbankan, Info Bank News. Com, 10 Juni 2008 (Diakses, 5 Desember 2014).

${ }^{42}$ Riza Primahendra, CSR Sebagai Investasi Sosial (Jakarta : Brief Note, Amerta Social Consulting \& Resourching, Edisi 8, 2010), 3.

${ }^{43}$ Shifa Mohd Nor, "Integrating Moral in a Dynamic Model of Corporate Social Responsibility in Islamic Economics and Finance"( Ph.D Student, School of

24 I INDO-ISLAMIKA, Volume 6 No.1 Januari - Juni 2016/1438 
spiritual bank syariah seharusnya memiliki dimensi spiritual lebih banyak, tidak hanya menghendaki bisnis non riba, melainkan juga mampu memberikan kesejahteraan bagi masyarakat yang lebih luas, terutama bagi golongan masyarakat ekonomi lemah. ${ }^{44}$

Penelitian lainnya menunjukkan bahwa bank syariah sebagai lembaga keuangan yang berbasis syariah dalam melaksanakan CSR masih menyimpang dari semangat Islam dan tidak berbeda dengan bank konvensional. ${ }^{45}$ Demikian pula dari sudut prinsip CSR dalam Islam yang masih bersifat umum, belum mencerminkan ajaran Islam dalam wujud operasional praktis yang dapat dipraktekkan pada perbankan syariah secara lebih spesifik. ${ }^{46}$ Bank syariah semestinya berperan sebagai lembaga percontohan dalam program $\mathrm{CSR}^{47} \mathrm{Hal}$ ini karena dibentuknya bank syariah adalah karena kritik terhadap bank konvensionalyang berprinsip atas dasar bunga dalam kegiatan perbankan. Praktek bunga telah dilaporkan memiliki efek negatif pada perkembangan sistem sosio-ekonomi masyarakat. ${ }^{48}$

Government and International Affairs, Durham University, Accepted, January 13, 2013), Asian and African Area Studies, 11(2) (2012), 137-150.

${ }^{44}$ Meutia Inten, "Shariah Enterprise Theory sebagai Dasar Pengungkapan Tanggung Jawab Sosial untuk Bank Syariah", Disertasi, Program Pasca Sarjana Universitas Brawijaya Malang (2010), dalam Erwanda, Edwin dan Mulawarman, Aji, Dedi, Tanggung Jawab Sosial pada Organisasi Perbankan Syariah, Studi Kasus pada BNI Syariah Cabang Malang (2013), 2.

${ }^{45}$ Mohamad Yazis Ali Basah and Mazlynda Md Yusuf, "Islamic Bank and Corporate Social Responsibility”, Management and Business, Vol.5, No.11 (2013), 194-209.

${ }^{46}$ Jawed Akhtar Mohammed, "Corporate Social Responsibility in Islam" (A. Thesis Submitted to Auckland University of Technology in Fultilment of the Requirements for The Degree of Doctor of Phildisosophy, Faculty of Business, New Zealand (2007), 101-140.

${ }^{47}$ Muhammad Yasir Yusuf, "Model Pelaksanaan CSR Bank Syariah (Kajian Empiris Pembiayaan Mikro Baitul Mal, Aceh)." La_Riba, Jurnal Ekonomi Islam, Volume IV, No. 2, Desember ( 2010),199.

${ }^{48}$ Muhammad Nejatullah Siddiqi "Issues in Islamic Banking", The Islamic foundation, Leicester, London, U.K., (1983/1403H), 152. Lihat juga Mohamed Ariff, "Islamic Banking", Asian-Pacific Economic Literature, Vol. 2, No. 2, September 1988), 46-62. Baca pula Lewis, Mervyn K. with L.M. Algaoud, "Islamic Banking." Edward Elgar, Cheltenham, UK and Northampton, Mass. (2001), 1-274. Lihat juga Ahmad, A. U. F. and Hassan, M. K, "Riba and Islamic Banking", Journal of Islamic Economics, Banking and Finance, 3 (1)(2007), 1-33. Baca pula Chong, B.S. and Liu, M. H, "Islamic Banking: Interest-Free or Interest-Based?", Pacific-Basin Finance Journal, 17, (2009), 125-144.

INDO-ISLAMIKA, Volume 6 No.1 Januari - Juni 2016/1438 I 25 
Bank konvensional, dalam pelaksanaan CSR memiliki kelemahan disebabkan oleh fokusnya lebih pada faktor sosial dan politik. ${ }^{49}$ Penelitian lainnya bahwa program CSR bagian dari promosi bank. ${ }^{50}$ Sedangkan Adeolu, mengungkapkan bahwa dengan pendekatan aspek ekonomi, sosial dan lingkungan dalam pembangunan berkelanjutan (sustanaibility development), secara umum korporasi harus mencurahkan lebih banyak sumber daya untuk kegiatan CSR dan merancang kebijakan/strategi dan mekanisme penegakan hukum di bidang pelaporan sosial dan lingkungan, dan kode etik pada suap dan korupsi. Bidang kesehatan perlu diberikan prioritas dalam pengeluaran dan peraturan CSR perusahaan. ${ }^{51}$

Praktek CSR dalam Islam erat kaitannya dengan perusahaanperusahaan yang menjalankan kegiatan bisnis sesuai dengan konsep syariah yang diharapkan perusahaan tersebut dapat melakukan tanggung jawab sosial perusahaan secara Islami. Berkembangnya CSR dalam ekonomi Islam juga turut meningkatkan perhatian masyarakat terhadap lembaga atau institusi syariah.

CSR di Indonesia belum dikembangkan secara sistematis, rasional dan tidak ada sinkronisasi antara ketentuan peraturan perundang-undangan, serta tidak adanya standar/acuan dalam melaksanakan program CSR sehingga implementasinya masih beraneka ragam dan masih terdapat perdebatan dari berbagai pemangku kepentingan. Walaupun telah diatur dalam Undang-undang No. 40 tahun 2007, Pasal 74 tentang keharusan Perseroan Terbatas melakukan tanggung jawab sosial dan lingkungannya. Jika program CSR tidak dilaksanakan maka Pemerintah dapat mengenakan sanksi

${ }^{49}$ Muhammad Taimoor Hassan et al, "Corporate Social Responsibility Disclosure (A. Comparison between Islamic and Conventional Financial Institutions in Bahawalpur Region)". International Journal of Learning Development, Vol. 2, No. 1 (2012), 51-62

${ }^{50} \mathrm{Md}$. Kayssar Ahmed, et al, "Corporate Social Responsibility Practices of Private Commercial Banks in Bangladesh: A Case Study on Southeast Bank Ltd," Developing Country Studies ISSN 2224-607X (Paper) ISSN 2225-0565 (Online)Vol. 4, No.14, (2014), 56-62.

${ }^{51}$ Adeolu O.Adewuju,et al, "CSR and Sustainable Community Development in Nigeria: WAPCO, a Case from The Cement Industry", Social Responsibility Journal, Vol. 6 Iss: 4, (2010), 522-535.

26 I INDO-ISLAMIKA, Volume 6 No.1 Januari - Juni 2016/1438 
sesuai dengan ketentuan undang-undang yang berlaku (Pasal 74 ayat $3)^{52}$

Pandangan yang berbeda dan merupakan kebalikan dari pandangan di atas adalah pandangan yang menolak CSR sebagai tanggung jawab perusahaan dan korporasi kepada masyarakat. Pada tahun 1970, ekonom Friedman ${ }^{53}$ menjelaskan pandangan yang berbeda tentang CSR bahwa tanggung jawab sosial perusahaan adalah menghasilkan keuntungan (profit) dalam batasan moral masyarakat dan hukum. Ia mengingatkan inisiatif perusahaan untuk menjalankan CSR dapat membuat arah manajemen menjadi tidak fokus, membuat pengelolaan sumber daya menjadi tidak efisien, memperlemah daya saing, serta mempersempit pilihan-pilihan dan kesempatan.

Persaingan perbankan yang ketat dan orientasi maksimasi keunt ungan, juga seringkali menyebabkan kecenderungan bank syariah untuk lebih melayani kelompok kuat dan profitable. Fungsi sosial bank syariah dalam memberikan fasilitas bagi keterkaitan antara voluntary sector dengan pemberdayaan ekonomi masyarakat belum optimal. ${ }^{54}$ Demikian pula perbankan konvensional dalam menjalankan aktivitas CSR lebih pada aktivitas sosial dan lingkungan, belum sepenuhnya berkontribusi dalam pemberdayaan ekonomi masyarakat.

\footnotetext{
${ }^{52}$ Undang-Undang Republik Indonesia Nomor 40 Tahun 2007, Tentang Perseroan Terbatas, diakses pada 10 Januari 2013.

${ }^{53}$ Milton Friedman, adalah seorang ekonom yang berasal dari Amerika yang lahir pada tahun 1912, ia memperoleh penghargaan Nobel pada tahun 1976 dibidang analisis konsumsi, teori, sejarah moneter dan demonstrasi kompleksitas dari kebijakan tentang stabilisasi, dan ia menentang konsep tanggung jawab sosial perusahaan, bahwa satu-satunya tanggung jawab perusahaan adalah memaksimumkan profit dan tanggung jawab sosial perusahaan adalah tanggung jawab para pemangku kepentingan. Lihat: Milton Friedman, "The Social Responsibility of Business is to Increase its Profits" dalam The New York Times Magazine, September 13, 1970, 214. Lihat juga dalam bukunya "Capitalism and Freedom" (The University of Chicago Press: 1962),133. Ia menyimpulkan bahwa doktrin tanggung jawab sosial merusak sistem ekonomi pasar bebas (free-enterprise). Doktrin ini juga bersifat ancaman terhadap masyarakat yang bebas dan demokratis, dengan peringatan yang serius bahwa masalah sosial biarlah menjadi urusan negara saja. Lihat juga T. Levitt, "The Dangers of Social Responsibility", Harvard Business Review, Vol. 33 No. 5, (1958), 41-50.

54 Tanaya Jimmy, Tanggung Jawab Sosial Korporasi, www.biro kredit Indonesia, 2006 (Diakses 12 Agustus 2014).
}

INDO-ISLAMIKA, Volume 6 No.1 Januari - Juni 2016/1438 I 27 
Para pendukung konsep CSR secara jelas dan tegas, berpendapat bahwa CSR sesungguhnya untuk kepentingan manusia dan kemanusiaan, sehingga harus diatur dengan jelas dan tegas. Sebaliknya, para penentangnya, menyatakan tidak perlu diatur dengan tegas, serahkan saja kepada para pelaku. CSR apabila dilaksanakan dengan benar, maka akan memberikan dampak positif bagi korporasi dan masyarakat. Perusahaan pada suatu waktu menjadi pusat kegiatan yang membawa kesejahteraan bahkan kemakmuran bagi masyarakat, dan pada saat yang sama dapat menjadi sumber petaka pada lingkungan yang sama pula. ${ }^{55}$

Pentingnya para peneliti memperluas studi tentang CSR yang lebih integratif, komunikatif dan distributif sehingga membentuk sinergi yang kuat dalam pembangunan berkelanjutan (sustanaible development). Dengan demikian akan dapat memerdayakan masyarakat (social empowerment) ${ }^{56}$. Social empowerment tersebut dapat dilihat melalui peningkatan kualitas kehidupan individu, kelompok masyarakat, terutama kelompok masyarakat marginal, seperti peningkatan pendapatan, kehidupan lingkungan sosial yang kondusif, peningkatan pendidikan, dan tingkat pengangguran menjadi rendah.

Pertumbuhan asset bank syariah, bila dibandingkan dengan bank konvensional tentulah sangat jauh perbedaannya, kalau bukan dapat dikatakan sebagai perbandingan antara langit dan bumi. Dalam hal ini bukanlah masalah besarnya asset yang menjadi ukurannya.

${ }^{55}$ Hendri, et, al, Persepsi Stakeholder Terhadap Pelaksanaan CSR : Kasus Pada Bank Syariah di DIY, Sinergi Kajian Bisnis dan Manajemen, Vol.10 No.1, Januari (2008), 19-30.

${ }^{56}$ Social Empowerment adalah suatu proses pribadi dan sosial; suatu pembebasan kemampuan pribadi, kompetensi, kreatifitas dan kebebasan bertindak (J. R. Robinson, "Community Development in Perspective." (Ames: Iowa State University Press 1994) dan M.Payne, Social Work and Community Care. (London: McMillan, 1997) menjelaskan bahwa pemberdayaan pada hakekatnya bertujuan untuk membantu klien mendapatkan daya, kekuatan dan kemampuan untuk mengambil keputusan dan tindakan yang akan dilakukan dan berhubungan dengan diri klien tersebut, termasuk mengurangi kendala pribadi dan sosial dalam melakukan tindakan. Orang-orang yang telah mencapai tujuan kolektif diberdayakan melalui kemandiriannya, bahkan merupakan "keharusan" untuk lebih diberdayakan melalui usaha mereka sendiri dan akumulasi pengetahuan, keterampilan serta sumber lainnya dalam rangka mencapai tujuan tanpa tergantung pada pertolongan dari hubungan eksternal (Diakses 12 Januari 2013).

28 I INDO-ISLAMIKA, Volume 6 No.1 Januari - Juni 2016/1438 
Dengan demikian, pertanyaan penting yang seharusnya dijawab adalah bagaimana bank tersebut mampu melaksanakan tanggung jawab sosialnya terhadap masyarakat? Pada saat yang sama menunjukkan bahwa realitas di lapangan berdasarkan studi empiris, bank-bank dalam menjalankan CSR belum optimal, karena pemanfaatannya hanya bersifat jangka pendek seperti charity dan voluntary, sehingga belum menyentuh pada akar permasalahan bangsa, yaitu pemberantasan kemiskinan, kebodohan, dan pengangguran.

Untuk memberikan jawaban bagi pertanyaan penting di atas, penulis perlu melakukan studi dan penelitian, yang lebih mendalam. Dalam penelitian ini, yang menjadi fokus penelitian adalah memberikan jawaban terhadap pertanyaan esensial yang bersifat substantif, yakni apakah tanggung jawab sosial korporasi mengandung nilai positif bagi masyarakat. Jadi CSR dapat mempunyai dampak positif bagi kehidupan masyarakat melalui memerdayakan masyarakat, tolak ukurnya adalah dapat dilihat dari aspek ekonomi, sosial dan lingkungan. ${ }^{57}$

Penelitian ini, lebih lanjut akan digiring kepada obyek penelitiannya, yaitu bank syariah dan bank konvensional yang terdaftar pada Bank Indonesia yang menerbitkan laporan tahunan secara periodik, dan lokasi penelitiannya di Wilayah Jabodetabek.

\section{B. Konsep dan Definisi CSR}

Sebenarnya konsep CSR bukanlah konsep charity atau belas kasihan semata-mata, tetapi merupakan konsep investasi untuk mengembangkan kapasitas masyarakat secara keseluruhan demi untuk pembangunan berkelanjutan (sustanaibility) yang dapat meningkatkan kualitas hidup masyarakat. ${ }^{58}$ Definisi CSR dalam perkembangannya sampai saat ini tidak ditemukan kajian yang murni. Sudah hampir satu dekade lamanya tidak ada upaya melacak

${ }^{57}$ John Elkington, Cannibals with Forks : The Triple Bottom Line Twentieth Century Business (Oxford : Capstone 1999 ), 20.

${ }^{58}$ Eko Murdiyanto, Muhammad Kundarto, Membangun Kemitraan Agribisnis Inovasi Program Corporate Social Responsibility (CSR) (Semarang: Yayasan Bina Karta Lestari, 2012), 30.

INDO-ISLAMIKA, Volume 6 No.1 Januari - Juni 2016/1438 I 29 
perkembangan definisi CSR yang semasif ${ }^{59}$ dan tidak ada pula upaya yang memetakan varian teori CSR. ${ }^{60}$

CSR merupakan salah satu bentuk tanggung jawab perusahaan terhadap masyarakat yang menekankan bahwa pemilik perusahaan mempunyai tanggung jawab terhadap masyarakat dan lingkungannya. Tanggung jawab sosial perusahaan dapat dipahami sebagai kebijakankebijakan dan tindakan-tindakan perusahaan dalam berintersaksi dengan lingkungannya yang didasarkan pada etika. ${ }^{61}$

Definisi CSR adalah tindakan atau konsep sosial yang dilakukan oleh sebuah perusahaan untuk membantu kehidupan termasuk didalamnya lingkungan, ekonomi, dan kesejahteraan masyarakat. Dengan adanya CSR perusahaan akan lebih mengedepankan sustainability dari pada profitability perusahaan. Melalui tindakannya itu akan membawa perbaikan pada apa yang telah dilakukannya dan kelak juga akan membawa dampak positif pada perusahaan berupa image perusahaan yang semakin baik di mata masyarakat.

Jika kita telusuri lebih dalam, maka CSR lebih banyak memiliki dampak positif dari pada dampak negatif. Karena bagaimanapun juga sesuatu hal yang akan membawa perbaikan dalam kualitas hidup adalah suatu tindakan mulia. Manusia itu merupakan mahluk sosial yang saling berinteraksi satu sama lainnya (simbiosis mutualisme), sehingga komunitas yang satu dengan yang lainnya saling membutuhkan dalam kehidupan bermasyarakat.

\section{Konsep dan Strategi Pemberdayaan masyarakat}

Konsep pemberdayaan masyarakat mulai tumbuh sejak tahun 1970-an dan mengalami perkembangan hingga tahun 1990-an. Konsep pemberdayaan memiliki pemikiran yang searah dengan berbagai aliran pemikiran yang berkembang pada akhir abad ke-20, yang dikenal dengan aliran posmodernisme. Aliran ini termasuk di dalamnya antara lain eksistensialisme, fenomologi, personalisme, neomarxisme, freudanisme serta berbagai aliran strukturalisme. Menitikberatkan

${ }^{59}$ Archie Carroll, "Corporate Social Responsibility, Evolution of a Definitional Construct," (Business and Society, Vol. 38/3, 1999), 268-295.

${ }^{60}$ Garriga and Mele, "Corporate Social Responsibility Theories: Mapping the Territory “ (Journal of Business Ethics, Vol. 53, 2004), 51-71.

${ }^{61}$ Poerwanto, Corporate Social Responsibilty, Menjinakkan Gejolak di Era Pornografi (Jakarta : Pustaka Pelajar, 2010), 19.

30 I INDO-ISLAMIKA, Volume 6 No.1 Januari - Juni 2016/1438 
pada sikap dan pendapat yang berorientasi pada jargon antisistem, antistruktur dan antideterminisme yang diaplikasikan pada dunia kekuasaan. ${ }^{62}$ Sampai saat ini terdapat berbagai macam perspektif yang berbeda mengenai konsep pemberdayaan masyarakat. Pada awalnya, konsep pemberdayaan bertujuan untuk menemukan alternatifalternatif baru dalam pembangunan masyarakat, disamping juga, menyangkut permasalahan bagaimana individu kelompok ataupun masyarakat berusaha mengontrol kehidupan mereka sendiri dan mengusahakan untuk membentuk masa depan sesuai dengan keinginan mereka. ${ }^{63}$

Pemberdayaan masyarakat harus terdapat unsur-unsur (a) Keinginan atau kebulatan tekad individu dan komunitas, (b) Nilai-nilai sosial yang dianut, (c) Rasa psikologis kontrol atau pengaruh personal dan sebuah perhatian terhada $\mathrm{p}$ pengaruh sosial, kekuatan politik dan hak-hak hukum yang sebenarnya. Di samping itu, harus ada pula kegiatan-kegiatan (a) Penyediaan sumber daya, (b) Penyediaan kesempatan, (c) Pembekalan pengetahuan dan ketrampilan dan (d) Pemberdayaan bertujuan agar masyarakat mempunyai kemampuan dan kemandirian dalam kehidupan mereka.

\section{Analisis CSR Terhadap Pemberdayaan Masyarakat Pada Bank Syariah}

Perusahaan sebagai salah satu pelaku dalam pembangunan ekonomi nasional, sudah selayaknya tidak hanya bertujuan memperoleh keuntungan finansial namun juga perlu berkontribusi bagi masyarakat dan lingkungan di sekitarnya. Tanggung jawab perusahaan kepada pemangku kepentingan (stakeholders) adalah untuk berlaku etis, meminimalkan dampak negatif dan memaksimalkan dampak positif yang mencakup aspek ekonomi, sosial dan lingkungan (triple bottom line) dalam rangka mencapai tujuan pembangunan berkelanjutan. ${ }^{64}$

Dalam penelitian ini, CSR dalam pendekatan teori triple bottom line (Triple $P=3 P$ ) tersebut, yaitu profit sebagai variabel

${ }^{62}$ Onny S. Prijono dan A. M. W. Pranarka, Pemberdayaan, Konsep, Kebijakan \& Implementasi (eds) (Jakarta : CSIS, 1996), 44-46.

${ }^{63}$ Adi Isbandi Rukminto, Pemikiran-Pemikiran dalam Pembangunan Kesejahteraan Sosial (Jakarta : Lembaga Penerbit FE-UI, 2002), 162-163.

${ }^{64}$ John Elkington, Cannibals with Forks : The Triple Bottom Line Twentieth Century Business (Oxford : Capstone 1999), 20.

INDO-ISLAMIKA, Volume 6 No.1 Januari - Juni 2016/1438 I 31 
ekonomi, people sebagai variabel sosial dan planet sebagai variabel lingkungan. Variabel lingkungan, disini dalam pendekatan pembangunan fisik, sesuai dengan program CSR yang dilakukan oleh bank syariah. Sebagaimana yang telah dikemukakan pada sub bab sebelumnya. CSR adalah jiwa perusahaan untuk mencapai tujuantujuan bisnis yang mencakup citra perusahaan, promosi, meningkatkan penjualan, membangun percaya diri, loyalitas karyawan serta keuntungan. ${ }^{65}$

Program CSR dalam bidang ekonomi, mencakup kegiatankegiatan yang berdampak pada peningkatan peluang kerja dan peluang usaha, peningkatan pendapatan dan penurunan kemiskinan di masyarakat. ${ }^{66}$ Program ini diharapkan untuk mampu membantu masyarakat dalam meningkatkan kehidupan ekonomi mereka, melalui berbagai program yang diberikan oleh bank syariah.

CSR dalam bidang sosial, merupakan hal yang sangat erat kaitannya dengan program-program CSR perusahaan. Masyarakat penerima manfaat dilihat sebagai subyek yang paling dekat dengan dampak yang dihasilkan oleh aktivitas perusahaan, oleh karenanya permaslahan sosial mendapat perhatian khusus oleh berbagai perusahaan dalam mengimplementasikan program-program CSR.

Bentuk kegiatan CSR bidang sosial, mencakup kegiatankegiatan sosial yang terkait dengan peristiwa yang terjadi seperti bencana alam, kebakaran, kebanjiran dan lainnya. Bentuk kegiatannya adalah dengan pemberian bantuan biaya hidup ataupun bantuan dalam bentuk lainnya. ${ }^{67}$

CSR dalam bidang lingkungan, mencakup kegiatan-kegiatan yang berdampak pada peningkatan kenyamanan dan kelestarian lingkungan. Dengan adanya CSR, diharapkan perusahaan mampu memberikan upaya optimalnya dalam memenuhi tanggung jawabnya tersebut pada lingkungan.

Program CSR yang dijalankan oleh perusahaan juga harus mampu memberikan cara yang solusif sehingga lingkungan dapat merasakan dampak positif dari program-program CSR. Idealnya upaya

${ }^{65}$ Poerwanto, Corporate Social Responsibilty, Menjinakkan Gejolak di Era Pornografi (Jakarta : Pustaka Pelajar, 2010), 21.

${ }^{66}$ http://www.btn.co.id/id/content/CSR/CSR/Kegiatan-CSR---PKBL-tahun2008 (Diakses, 5 desember 2015).

${ }^{67}$ Bank Muamalat, "Laporan Good Corporate Governance PT Bank Muamalat Indonesia Tbk", Bank Muamalat (2014), 121.

32 I INDO-ISLAMIKA, Volume 6 No.1 Januari - Juni 2016/1438 
tanggung jawab akibat aktivitas perusahaan harus masuk kedalam agenda wajib bagi perusahaan, namun seringkali ditemukan program CSR bidang lingkungan yang masih mengikutsertakan penanggulangan kerusakan lingkungan akibat aktivitas perusahaan tersebut ke dalam program CSR. $^{68}$

Dalam penelitian ini, untuk menguji dampak CSR bank syariah terhadap pemberdayaan masyarakat, maka digunakan analisis regresi linier berganda (multiple linear regression analysis). ${ }^{69}$ Analisis regresi linier berganda digunakan dalam penelitian ini dengan tujuan untuk membuktikan hipotesis mengenai pengaruh variabel - variabel CSR seperti ekonomi, sosial dan lingkungan secara simultan ${ }^{70}$ maupun secara parsial ${ }^{71}$ terhadap pemberdayaan masyarakat penerima manfaat.

${ }^{68}$ Intan Kirana, Peran CSR Bidang Lingkungan Dalam Menunjang Perolehan Progran Penilaian Peringkt Kinerja Perusahaan (Proper) PT Surya Kertas, Jurnal $\begin{array}{llllll}\text { Ilmiah Mahasiswa USU Vol. } 2 & \text { (2) (2009), } & \text { 1-15 }\end{array}$ http://Journal.ubaya.ac.id/index.php/jimus/article/view/329/320 (Diakses 2 Januari 2016).

${ }^{69}$ Analisa regresi linier berganda adalah suatu teknik yang digunakan untuk membangun suatu persamaan yang menghubungkan antara variabel tidak bebas (dependent variable $=\mathrm{Y}$ ) dengan beberapa variabel bebas (independent variabel $=\mathrm{X}$ ). Tujuan analisis regresi linear berganda adalah untuk memperkirakan perubahan respons pada variabel terikat terhadap beberapa variabel bebas. (Suharyadi, Poerwanto S. K, Statistika untuk Ekonomi dan Keuangan Modern (Jakarta: Salemba Empat, 2004), 469.

${ }^{70}$ Simultan (Uji F) adalah menguji pengaruh/dampak variabel-variabel bebas secara serentak/bersama-sama terhadap variabel terikat. Signifikan berarti hubungan yang terjadi dapat berlaku untuk populasi.Penggunaan tingkat signifikansinya beragam, tergantung keinginan peneliti, yaitu 0,01 (1\%); 0,05 (5\%) dan 0,10 (10\%). Hasil uji $\mathrm{F}$ dilihat dalam tabel ANOVA dalam kolom sig. Sebagai contoh, kita menggunakan taraf signifikansi 5\% $(0,05)$, jika nilai probabilitas lebih kecil dari 0,05 , maka dapat dikatakan terdapat pengaruh yang signifikan secara bersama-sama antara variabel bebas terhadap variabel terikat, namun, jika nilai signifikansi lebih besar dari 0,05 maka tidak terdapat pengaruh yang signifikan secara bersama-sama antara variabel bebas terhadap variabel terikat.

${ }^{71}$ Parsial (Uji t) adalah untuk menguji pengaruh/dampak masing-masing variabel bebasnya secara sendiri-sendiri/terpisah terhadap variabel terikatnya. Hasil uji t dapat dilihat pada tabel coefficients pada kolom sig (significance). Jika probabilitas nilai $t$ atau signifikansi lebih kecil dari 0,05 , maka dapat dikatakan bahwa terdapat pengaruh antara variabel bebas terhadap variabel terikat secara parsial.Namun, jika probabilitas nilai $\mathrm{t}$ atau signifikansi $>0,05$, maka dapat dikatakan bahwa tidak terdapat pengaruh yang signifikan antara masing-masing

INDO-ISLAMIKA, Volume 6 No.1 Januari - Juni 2016/1438 I 33 
Perhitungan statistik dalam analisis regresi linier berganda yang digunakan dalam penelitian ini adalah dengan menggunakan bantuan sofware SPSS versi 16.0.Sebelum menggunakan hasil analisis regresi berganda di dalam penelitian, terdapat beberapa asumsi dasar yang harus dipenuhi terlebih dahulu.Asumsi-asumsi tersebut dinamakan uji asumsi klasik.

Pada penelitian ini akan dilakukan tiga uji asumsi klasik, yaitu uji normalitas, uji multikolinearitas dan uji heteroskedastisitas data. Model regresi penelitian dengan variabel independendnya, yaitu variabel ekonomi $\left(\mathrm{X}_{1}\right)$, variabel sosial $\left(\mathrm{X}_{2}\right)$ dan variable lingkungan $\left(\mathrm{X}_{3}\right)$. Variabel dependentnya yaitu pemberdayaan masyarakat $(\mathrm{Y})$.

Berdasarkan hasil uji regresi dapat diketahui bahwa CSR yang terdiri dari variabel ekonomi $\left(\mathrm{X}_{1}\right)$, variabel sosial $\left(\mathrm{X}_{2}\right)$ dan variabel lingkungan $\left(\mathrm{X}_{3}\right)$, memiliki pengaruh/dampak terhadap pemberdayaan masyarakat. Sebagaimana disajikan dalam tabel 4.16 yang menggambarkan uji $\mathrm{F}$ memperlihatkan ketiga variabel independen tersebut di atas secara bersama-sama (simultan) mempunyai dampak yang signifikan terhadap pemberdayaan masyarakat.

Tabel 4.16 menggambarkan hasil uji $\mathrm{F}$, diperoleh nilai probabilitas sig sebesar 0,00 di mana nilai tersebut lebih kecil dari 0,05 atau $(\alpha=5 \%)$, sehingga dapat disimpulkan bahwa ada pengaruh/dampak antara CSR secara simultan atau secara bersamasama terhadap pemberdayaan masyarakat. Artinya bahwa, bank syariah telah menjalankan program CSR di bidang pemberdayaan ekonomi, sosial dan lingkungan.Dapat dilihat pada pembahasan yang lebih terperinci dari masing-masing variabel dalam pengujian secara parsial atau terpisah (uji t).

Tabel 4.16 Hasil Uji F

\begin{tabular}{|l|l|r|r|r|r|r|}
\hline \multicolumn{2}{|c|}{ ANOVA $^{\text {b }}$} & \multicolumn{1}{c|}{ Sig. } \\
\multicolumn{2}{|c|}{ Model } & $\begin{array}{c}\text { Sum of } \\
\text { Squares }\end{array}$ & Df & $\begin{array}{c}\text { Mean } \\
\text { Square }\end{array}$ & F & Sig. \\
\hline \multirow{2}{*}{1} & Regression & 15.641 & 3 & 5.214 & 57.900 & $.000^{\mathrm{a}}$ \\
\cline { 2 - 7 } & Residual & 5.943 & 66 & .090 & & \\
\cline { 2 - 7 } & Total & 21.584 & 69 & & & \\
\hline
\end{tabular}

a. Predictors: (Constant), Aspek Lingkungan, Aspek Ekonomi, Aspek Sosial

b. Dependent Variable: Pemberdayaan Masyarakat

variabel bebas terhadap variabel terikat. Uji t juga bisa dilakukan dengan bantuan software SPSS.

34 I INDO-ISLAMIKA, Volume 6 No.1 Januari - Juni 2016/1438 
Penelitian ini sejalan dengan penelitian yang dilakukan oleh Chintaman, bahwa bank syariah lebih inovatif dalam praktek CSR dan berpegang teguh pada nilai-nilai Islam. ${ }^{72} \mathrm{Hal}$ ini, jika diukur dari keseluruhan variabel. Penelitian ini juga sejalan dengan teori yang dibangun oleh Jhon Elkington, ${ }^{73}$ mengimplikasikan bahwa perusahaan harus lebih mengutamakan kepentingan semua pihak yang terlibat dan terkena dampak dari kegiatan yang dilakukan perusahaan.

Hasil perhitungan regresi dapat diketahui bahwa Koefisien Determinasi (Adjusted R Square) yang diperoleh dari nilai $R$-Square sebesar 0.725 atau $72,5 \%$, hal ini menunjukkan bahwa hubungan variabel independen terhadap variabel dependen adalah kuat. Besarnya adjusted $R$ Square 0,712 atau $71,2 \%$, hal ini berarti bahwa semua variabel independen (Ekonomi, Sosial dan Lingkungan ) mampu menjelaskan variabel dependen (Pemberdayaan Masyarakat) sebesar $71,2 \%$ dan sisanya $(100 \%-71,2 \%)=28,8 \%$ dapat dipengaruhi oleh variabel-variabel atau faktor-faktor lain yang tidak dijelaskan dalam penelitian ini, sebagaimana disajikan dalam tabel 4.17 dibawah ini.

\section{Tabel 4.17 Koefisien Determinasi Model Summary ${ }^{\mathrm{b}}$}

\begin{tabular}{|l|r|r|r|r|c|}
\hline Model & R & R Square & $\begin{array}{c}\text { Adjusted R } \\
\text { Square }\end{array}$ & $\begin{array}{c}\text { Std. Error of } \\
\text { the Estimate }\end{array}$ & $\begin{array}{c}\text { Durbin- } \\
\text { Watson }\end{array}$ \\
\hline 1 & $.851^{\mathrm{a}}$ & .725 & .712 & .30008 & 1.914 \\
\hline
\end{tabular}

a. Predictors: (Constant), Aspek Lingkungan, Aspek Ekonomi, Aspek Sosial

b. Dependent Variable: Pemberdayaan Masyarakat

Hal ini sejalan dengan teori yang dibangun oleh Jim fe,$^{74}$ bahwa dalam pemberdayaan masyarakat, interaksi variabel-variabel ekonomi, sosial, lingkungan, politik, budaya, dan spiritual tidak

${ }^{72}$ S. A. Chintaman, dalam "A Comparative Study of CSR Practices of Islamic Banks and Conventional Banks in GCC Region", Journal of Islamic Banking and Finance Vol. 2, No. 1, (March 2014), 1-21. Department of Commerce and Accountancy, Shri H. K. Commerce College, Gujarat University, India.

${ }^{73}$ John Elkington, Cannibals with Forks : The Triple Bottom Line Twentieth Century Business (Oxford : Capstone 1999), 20.

${ }^{74} \mathrm{Jim}$ Ife \& Frank Tesoriero, "Community Development : Creating Communty Alternatives, Vision, Analysis and Practice ( Australia: Longman,1995), 56.

INDO-ISLAMIKA, Volume 6 No.1 Januari - Juni 2016/1438 I 35 
semuanya akan setara, namun sesuai dengan situasi dan kondisi serta level-level masyarakat. Artinya masing-masing variabel akan memiliki dampak positif atau negatif terhadap pemberdayaan masyarakat, tergantung pada situasi dan kondisi saat penelitian tersebut dilakukan.

Berdasarkan temua-temuan penelitian tersebut di atas, bahwa dari sisi ekonomi, sosial dan lingkungan, bank syariah telah menjalankan program CSR, sesuai dengan tujuan CSR yaitu ikut berperan serta dalam pembangunan berkelanjutan (sustainable development) yang dikemukakan oleh Carrol.$^{75}$

Pemberdayaan ekonomi masyarakat merupakan usaha untuk menjadikan ekonomi yang kuat, besar, modern, dan berdaya saing tinggi dalam mekanisme pasar yang benar.Pemberdayaan ekonomi tidak cukup hanya dengan peningkatan pendapatan atau penghasilan, memberikan kesempatan berusaha yang sama, kesempatan untuk memperoleh lapangan pekerjaan, dan hanya memberikan suntikan modal sebagai stimulan, tetapi harus dijamin adanya kerjasama dan kemitraan yang erat antara yang telah maju dengan yang masih lemah dan belum berkembang. ${ }^{76}$

Pelaku usaha mikro kecil dan menengah /UKM belum dapat menyerap tenaga kerja secara potensial, biasanya masih dalam sistem kekeluargaan dalam menjalankan usahanya. Bahkan tidak sedikit yang merupakan usaha turun temurun dari kakek, anak dan hingga cucunya. Usaha yang mereka jalankan masih berskala kecil, pengelolaan masih bersifat tradisionil,dan mereka tidak mampu bersaing dengan mini market yang banyak tumbuh disekitar lingkungan masyarakat sehingga mematikan para pedangang kecil yang modal usahanya masih sangat kecil.

Bank syariah, sebagai bank yang memiliki karakteristik khas yang saling bersinergi, antara karakteristik teologis, konsep maupun operasinya yang berdasarkan pada tiga pilar pokok ajaran agama

${ }^{75}$ A. B. Carroll, The Pyramid of Corporate Social Responsibility: Toward the Moral Management of Organizational Stakeholders, Business Horiz ons 34, (1991), 39- 48.

${ }^{76}$ Gunawan Sumidiningrat, Pemberdayaan Masyarakat dan Jaring Pengaman Sosial (Jakarta : Gramedia 1999), Dikutif dalam Mardi Yatmo Hutomo, Pemberdayaan Masyarakat dalam Bidang Ekonomi: Tinjauan Teoritik dan Implementasi.

http://www.bappenas.go.id/files/2913/5022/6062/mardi_ 2009101515103523 840.pdf (Diakses, 3 Desember 2015).

36 I INDO-ISLAMIKA, Volume 6 No.1 Januari - Juni 2016/1438 
1slam. Tiga pilar pokok ajaran lslam mencakup aqīdah, shari' ah dan akhlāq. ${ }^{77}$ Bank syariah seharusnya menunjukkan peran nyata sebagai lembaga keuangan yang memiliki keberpihakan ideologis terhadap perkembangan perekonomian rakyat kecil.

Salah satu kekhasan bank syariah adalah bahwa produkproduknya tidak saja berorientasi bisnis-komersial, tetapi juga mempunyai fungsi sosial (socio economical benefits). Pada bank syariah terdapat jenis pembiayaan yang dinamakan qard al-hasan (benevolent loan/pinjaman kebajikan), yaitu pembiayaan yang disalurkan tanpa imbalan apapun. Dana qarḍ al-hasan bersumber dari pendapatan non halal (seperti bunga), denda, zakat, infaq dan sedekah. ${ }^{78}$ Dana tersebut yang dijadikan sebagai sumber pembiayaan CSR pada bank syariah untuk berkontribusi dalam pembangunan berkelanjutan (sustanaible development).

Pada akhirnya pemberdayaan masyarakat, merupakan proses untuk membuat masyarakat menjadi berdaya.Setiap anggota masyarakat dalam sebuah komunitas sebenarnya memiliki potensi, gagasan serta kemampuan untuk membawa dirinya dan komunitasnya untuk menuju ke arah yang lebih baik, namun potensi itu terkadang tidak bisa berkembang disebabkan faktor-faktor tertentu. Untuk menggerakkan kembali kemandirian masyarakat. ${ }^{79}$ Oleh karena itu peran bank syariah sangat diperlukan dalam membantu meningkatkan kesejahteraan umat, terutama umat muslim.

\section{Analisis Aspek Ekonomi Terhadap Pemberdayaan Masyarakat}

Masyarakat merupakan bagian dari komunitas perusahaan, yang memiliki peran serta dalam keberhasilan pembangunan berkelanjutan (sustainable development). Masyarakat sebagai penerima manfaat dalam penerapan program CSR oleh perusahaan

${ }^{77}$ Achmad Baraba, "Prinsip Dasar Operasional Perbankan Syariah,"Buletin Ekonomi Moneter dan Perbankan (BEMP), Volume 2 Nomor 3, Desember (1999), 2 wunrv.bi.go.id. (Diakses 3 Desember 2015).

${ }^{78}$ Peran Bank Syariah Dalam Pengentasan Kemiskinan https://simpelbisnis.wordpress.com/2010/09/14/peran-bank-syariah-dalampengentasan-kemiskinan/ (Diakses, 4 Desember 2015).

${ }^{49}$ Katharina, et al, Implementasi ProgramNasional Pemberdayaan Masyarakat Mandiri Perkotaan di Kecamatan Poasia dan Kecamatan Kambu Kota Kendari.

http://pasca.unhas.ac.id/jurnal/files/d5fae71b6855dcc800ffc75d0d054b2e.pdf (Diakses, 5 Januari 2016). 
sering kali tidak menjadikan masyarakat sebagai faktor utama yang menentukan keberhasilan program. Peran serta masyarakat dibatasi hanya sebatas pada pelaksanaannya saja, sehingga masyarakat tidak berdaya dan tidak berkembang kreativitasnya. Pada akhirnya masyarakat bersikap pasif dan tidak memiliki kesadaran kritis. ${ }^{80}$

Bank syariah untuk mempertahankan eksistensinya selain tentunya menjalankan orientasi bisnisnya (profit), juga harus memperhatikan dan terlibat langsung dalam pemenuhan kesejahteraan masyarakat, terutama masyarakat ekonomi lemah (miskin), khususnya di sekitar lingkungannya. Salah satu strateginya adalah dengan melaksanakan program CSR.

Pelaksanaan kegiatan CSR bank syariah diperkuat oleh beberapa faktor pendorong, baik yang berasal dari internal mapun eksternal perusahaan. Faktor pendorong yang berasal dari lingkungan internal perusahaan berkaitan dengan komitmen dan kesadaran seluruh manajemen dan karyawan, berperan serta menciptakan kondisi kehidupan yang lebih baik untuk pihak di sekitar kegiatan operasional perusahaan. $^{81}$

Di sisi lain, pelaksanaan kegiatan CSR bank syariah juga didukung oleh faktor eksternal berupa dukungan Pemerintah dan pedoman peraturan perundang-undangan untuk memperkuat praktik $\mathrm{CSR}^{82}$ Dalam aplikasinya, kegiatan CSR bank syariah tidah hanya melakukan program pemberian bantuan (charity), namun lebih jauh berkomitmen untuk menjadikan filosofi dan tujuan CSR sebagai bagian yang tak terpisahkan dari aktivitas perusahaan, yang berpijak pada konsep pemberdayaan masyarakat berkelanjutan. ${ }^{83}$

Secara umum bank syariah dalam menentukan kebijakan program CSR salah satunya adalah membidangi ekonomi. ${ }^{84}$ Dalam aspek ekonomi, bank syariah memiliki tujuan untuk menciptakan masyarakat yang mandiri, melalui program pemberdayaan ekonomi.

${ }^{80}$ Nasdian Fredian Tonny, Pengembangan Masyarakat (Institut Pertanian Bogor, 2006), 23.

${ }^{81}$ Bank Syariah Mandiri, "Laporan Good Corporate Governance PT Bank Syariah Mandiri”, Bank Syariah Mandiri (2012), 151.

${ }^{82}$ BNI Syariah, Laporan Tahunan, Annual Report PT Bank BNI Syariah Tbk, Bank BNI Syariah (2012), 173.

${ }^{83}$ BNI Syariah (2012), 174.

${ }^{84}$ Aspek ekonomi ini mengacu pada CSR dalam pendekatan teori Triple Bottom Line, Jhon Elkington (1999),20.

38 I INDO-ISLAMIKA, Volume 6 No.1 Januari - Juni 2016/1438 
Kegitan pemberdayaan ekonomi bertujuan mewujudkan usaha kecil efisien, sehat dan mandiri, selanjutnya usaha kecil mampu menjadi kekuatan ekonomi kerakyatan yang memberikan sumbangan besar bagi pembangunan nasional. ${ }^{85}$

Program pemberdayaan ekonomi, dikembangkan untuk membangun usaha-usaha kecil dan menengah di kelompok atau komunitas Islam, seperti pesantren, pembinaan remaja putus sekolah, kelompok ibu-ibu, ${ }^{86}$ Bentuk kegiatan yang dilakukan antara lain pembinaan, pengembangan dan pemberdayaan ekonomi umat melalui bantuan modal, pelatihan dan pendampingan usaha secara perorangan dan kelompok/LKMS. ${ }^{87}$

Salah satu kebijakan bank syariah dalam tanggung jawab sosial perusahaannya, yaitu "Commitment for Economic Empowerment" yang merupakan program CSR untuk memberdayakan ekonomi masyarakat agar menjadi masyarakat yang mandiri dan unggul dengan mendukung dan memotivasi masyarakat setempat di daerah masingmasing. ${ }^{88}$

Pemberdayaan masyarakat dapat diartikan sebagai suatu upaya untuk memulihkan atau meningkatkan keberdayaan suatu komunitas agar mampu berbuat sesuai dengan harkat dan martabat mereka dalam melaksanakan hak-hak dan tanggung jawab mereka sebagai komunitas manusia dan warga negara. ${ }^{89}$

Dalam penelitian ini, aspek ekonomi merupakan variable independent yang menggambarkan kondisi ekonomi masyarakat penerima manfaat program CSR yang diselenggarakan oleh bank syariah. Pemberdayaan masyarakat sebagai variable dependen yang menggambarkan bagaimana kondisi keberdayaan masyarakat penerima manfaat. Keberdayaan masyarakat penerima manfaat dalam aspek ekonomi, dapat dilihat dari kemampuan ekonomi, kemampuan daya beli, kemampuan berinvestasi (menabung) dan lainnya.

${ }^{85}$ Bank Syariah Mandiri, Laporan Good Corporate Governance PT Bank Syariah Mandiri”, Bank Syariah Mandiri (2014), 253.

${ }^{86}$ BNI Syariah, Laporan Tahunan, Annual Report PT Bank BNI Syariah, BNI Syariah (2014), 350.

${ }^{87}$ Bank Syariah Mandiri,(2014), 252.

${ }^{88}$ BNI Syariah (2013),220-231

${ }^{89}$ Erni Febrina H, Pemberdayaan Masyarakat Dalam Bidang Ekonomi untuk Mewujudkan Ekonomi Nasional yang Tangguh dan Mandiri, Jurnal Manajemen dan Kewirausahaan, Volume 3, Nomor 2, Mei 2012 ISSN : 2086 - 5031: 78-96.

INDO-ISLAMIKA, Volume 6 No.1 Januari - Juni 2016/1438 I 39 
Untuk melihat bagaimana keberdayaan ekonomi masyarakat penerima manfaat setelah adanya kegiatan program CSR yang dilakukan oleh bank syariah, maka dilakukan pengujian secara parsial atau terpisah (uji signifikansi/uji t). Tujuan pengujian ini adalah untuk menguji variabel aspek ekonomi terhadap pemberdayaan masyarakat, sebagaimana yang tertera dalam tabel 4.18.

Hasil pengujian untuk variabel aspek ekonomi menunjukkan nilai $\mathrm{t}=5,266$ dengan nilai signifikansi sebesar 0,000 lebih kecil dari 0,05 . Dengan nilai signifikansi di bawah 0,05 tersebut menunjukkan bahwa variabel aspek ekonomi memiliki dampak yang signifikan dan positif terhadap pemberdayaan masyarakat penerima manfaat. Hal ini menunjukkan bahwa bank syariah dalam melaksanakan program CSR sesuai dengan misinya yaitu "Melaksanakan program-program pemberdayaan ekonomi dan sosial masyarakat secara terintegral dan komprehensif, membangun dan mengembangkan jaringan kerja serta pemberdayaan masyarakat secara seluas-luasnya." ${ }^{90}$

Tabel 4.18 Uji Parsial (Uji t) Aspek Ekonomi

\begin{tabular}{|l|c|c|c|c|c|}
\hline \multicolumn{7}{|c|}{ Coefficients $^{\text {a }}$} \\
\hline Model & \multicolumn{2}{|c|}{$\begin{array}{c}\text { Unstandardized } \\
\text { Coefficients }\end{array}$} & $\begin{array}{c}\text { Standardized } \\
\text { Coefficients }\end{array}$ & T & Sig. \\
\cline { 2 - 6 } & B & $\begin{array}{c}\text { Std. } \\
\text { Error }\end{array}$ & Beta & & \\
\hline $\begin{array}{l}\text { Aspek } \\
\text { Ekonomi }\end{array}$ & .343 & .065 & .442 & 5.266 & .000 \\
\hline
\end{tabular}

Sumber : Data diolah

Bank syariah dalam mengelola dana CSR, bekerjasama dengan Lembaga Swadaya Masyarakat/LSM, seperti Lembaga Dompet Dhuafa. ${ }^{91}$ Mendirikan Baitul Māl Wa Tamwil atau KJKS (

${ }^{90}$ Bank Muamalat, "Laporan Good Corporate Governance PT Bank Muamalat Indonesia Tbk", Bank Muamalat (2014), 130.

${ }^{91}$ Dalam rangka merealisasikan program tanggung jawab sosial, BNI Syariah bekerjasama melimpahkan dana zakat kepada Yayasan Hasanah Titik (YHT) untuk disalurkan dalam kegiatan sosial.YHT dalam pelaksanaannya bekerjasama dengan Lembaga Amil Zakat Nasional Dompet Dhuafa yang diatur dalam MoU No.201/LAZDD.DIR-LEGAL/III/2014.BNI Syariah, Laporan Tahunan, Annual Report PT Bank BNI Syariah Tbk, Bank BNI Syariah (2014), 346-359.

40 I INDO-ISLAMIKA, Volume 6 No.1 Januari - Juni 2016/1438 
Koperasi Jasa Keuangan Syariah). ${ }^{92}$ Tujuannya adalah agar lebih fokus dalam menjalankan kegiatan CSR dan dapat memberikan hasil yang lebih maksimal serta lebih profesional. ${ }^{93}$ Bentuk kerjasamanya adalah pengelolaan dana CSR, zakat karyawan, nasabah dan masyarakat pada umumnya.

Bentuk program pemberdayaannya meliputi pengembangan masyarakat (Community Development), pemberdayaan ekonomi (economic empowerment), Micro Finance ; Islamic Social Fund, Micro Entrepreneur. Pendidikan, lingkungan dan kesehatan, bidang sosial dan dakwah. ${ }^{94}$ Program-program tersebut menjadi motor penggerak program kemandirian ekonomi ummat menuju terwujudnya tatanan masyarakat yang berkarakter, tumbuh dan peduli (empowering a caring society). ${ }^{95}$

Dari sisi penerima manfaat, program CSR harus disesuaikan dengan ketentuan syariat yang mengatur dengan tegas kelompokkelompok penerima program, yaitu kelompok-kelompok masyarakat yang masuk kategori ashnaf diantaranya fakir, orang-orang miskin, pengurus-pengurus zakat/amil, Para mu'allaf yang dibujuk hatinya, untuk (memerdekakan) budak, orang-orang yang berhutang, untuk jalan Allah dan untuk mereka yang sedang dalam perjalanan (musāfir). ${ }^{96}$

Pelaksanaan pemberdayaan ekonomi masyarakat pada bank syariah dalam bentuk pembinaan dan pengembangan ekonomi umat, yaitu pengembangan Usaha Kecil Menengah/UKM yang ada dalam masyarakat. Bantuan yang diberikan tanpa jaminan atau penjamin kepada masyarakat kecil miskin yang kurang mampu, tetapi mempunyai potensi untuk mengembangkan usaha perekonomiannya.

${ }^{92}$ Bank Muamalat, dalam program CSR mendirikan lembaga Baitul māl Muamalat (BMM). Program yang dijalankan oleh BMM adalah pemberdayaan ekonomi mikro, dimana targetnya adalah para nasabah atau anggota BMT (Baitul Māl Wa Tamwil), KJKS ( Koperasi Jasa Keuangan Syariah) yang telah menjadi mitra dari BMI dalam penyaluran zakat sejak sebelum yayasan BMM didirikan.Program-programnya mencakup bidang ekonomi, pendidikan, kesehatan dan sosial.

${ }^{93}$ Bank Muamalat, "Laporan Good Corporate Governance PT Bank Muamalat Indonesia Tbk", Bank Muamalat (2011), 125.

${ }^{94}$ BNI Syariah (2014), 346-359. Baca juga Bank Muamalat (2014), 130.

${ }^{95}$ Bank Muamalat (2014), 130.

${ }^{96}$ BNI Syariah (2014), 346-359.

INDO-ISLAMIKA, Volume 6 No.1 Januari - Juni 2016/1438 | 41 
Jika anggota meninggal dunia, mereka dibebaskan dari pembayaran kredit.

Bank syariah mengorganisasir masyarakat miskin yang menjadi peminjamnya dalam kelompok-kelompok kecil yang terdiri atas lima anggota.Tujuannya adalah untuk memperkuat peminjam sehingga mereka dapat merencanakan dan pengambilan keputusan pada tingkat mikro.Dalam hal penyaluran kredit, tetap diprioritaskan pada kelompok yang membutuhkan dana untuk menunjang keberhasilan usahanya. $^{98}$

Pemberian bantuan tidak didasarkan atas kedermawanan atau belas kasihan, karena akan menimbulkan ketergantungan kepada pihak lain. Bantuan kredit yang telah diberikan harus dapat menyiapkan persyaratan dan prosedur kredit yang sesuai dengan kondisi masyarakat, artinya bersifat fleksibel, serta tidak mensyaratkan adanya agunan atau jaminan anggota. Pengelolaan bantuan kredit itu sendiri harus dilakukan secara terbuka dan profesional dengan berprinsip dari, oleh dan untuk anggota.

Penyaluran kredit dana kebajikan (qard al hasan) bersumber dari Denda (ta'zir), Pendapatan non halal dan dana sosial lainya. Dana zakat bersumber dari zakat perusahaan, zakat nasabah dan umum, serta zakat pegawai, ditambah dari infaq, sedekah dan wakaf (Ziswaf). Denda merupakan keterlambatan pembayaran dari nasabah debitur yang disengaja. Pendapatan non halal (pendapatan dari penempatan dana di bank konvensional/bunga. ${ }^{99}$ Pendapatan non halal, maksudnya adalah pendapatan bunga yang diperoleh dari investasi atau penempatan dana di bank konvensional, dimana bank konvensional menerapkan konsep bunga dan bank syariah menerapkan profit sharing atau bagi hasil.

Secara umum bank syariah telah berhasil menjalankan program CSR di bidang pemberdayaan ekonomi masyarakat. Kegiatan-

97 Tisna Prenanto,’Peran Bank Syariah dalam Mengembangkan Usaha Kecil Menengah"http://www.kompasiana.com/sangsurya/peran-bank-syariah-dalammengembangan-usaha-kecil-menengah_5517d225a333114907b6616c (Diakses, 30 Maret 2016)

${ }^{98} \mathrm{http}: / /$ www.kompasiana.com/sangsurya/peran-bank-syariah-dalammengembangan-usaha-kecil-menengah_5517d225a333114907b6616c (Diakses, 30 Maret 2016)

${ }^{99}$ Bank Muamalat, "Laporan Good Corporate Governance PT Bank Muamalat Indonesia Tbk", Bank Muamalat (2014), 130.

42 I INDO-ISLAMIKA, Volume 6 No.1 Januari - Juni 2016/1438 
kegiatan yang diselenggarakan antara lain kegiatan pemberdayaan ekonomi seperti pemberian bantuan ternak domba, budidaya lele, pemberian grobak kepada pedagang kecil. ${ }^{100}$ Melakukan pelatihan keterampilan kepada para pedagang kecil, berupa pelatihan kewirausahaan, pengelolaan keuangan, pelatihan komputer. Masyarakat diberikan pelatihan tanpa dipungut biaya. Mereka dilatih secara profesional dengan tujuan agar mereka menjadi wirausaha mandiri, sehingga dapat memenuhi kebutuhan hidupnya sendiri, dan ditargetkan agar dapat menyerap tenaga kerja.

Dalam Islam diajarkan nilai-nilai dasar ekonomi yang bersumber pada ajaran tauhid. Islam lebih dari sekedar nilai-nilai dasar etika ekonomi, seperti: keseimbangan, kesatuan, tanggung jawab dan keadilan, tetapi juga memuat keseluruhan nilai-nilai yang fundamental serta norma-norma yang substansial agar dapat diterapkan dalam kehidupan bermasyarakat. ${ }^{101}$

Basis utama sistem ekonomi syari'ah sesungguhnya terletak pada aspek kerangka dasarnya yang berlandaskan syari'at, tetapi juga pada aspek tujuannya yaitu mewujudkan suatu tatanan ekonomi masyarakat yang sejahtera berdasarkan keadilan, pemerataan dan keseimbangan.

Pembangunan ekonomi Islam dibangun berdasarkan prinsip tauhid dan etika serta mengacu pada tujuan syari'at (maqāshid alshari' 'ah) yaitu memelihara iman (faith), hidup (life), nalar (intellect), keturunan (posterity) dan kekayaan (wealth). Konsep ini menjelaskan bahwa sistem ekonomi hendaknya dibangun berawal dari suatu keyakinan (iman) dan berakhir dengan kekayaan (property). Pada gilirannya tidak akan muncul kesenjangan ekonomi atau perilaku ekonomi yang bertentangan dengan prinsip-prinsip syari' at. ${ }^{102}$

Pada prinsipnya pemberdayaan ekonomi masyarakat, merupakan tanggung jawab seluruh masyarakat di muka bumi ini, terutama masyarakat muslim sesuai dengan ajaran yang dibawa oleh

${ }^{100}$ BNI Syariah, Laporan Tahunan, Annual Report PT Bank BNI Syariah Tbk, Bank BNI Syariah (2012), 168-187.

${ }^{101} \mathrm{http}: / / w w w . f s h u i n s g d . a c . i d / 2012 / 03 / 23 /$ paradigma-ekonomi-islam-olehahmad-hasan-ridwan/ (Diakses, 3 Januari 2016)

102 M. Umer Chapra,."Strategi Pembangunan Ekonomi Di Negara-Negara Muslim: Persfektif Ajaran Islam". Jurnal Bisnis dan Ekonomi Islam"Equilibrium” Volume 01.2005.

INDO-ISLAMIKA, Volume 6 No.1 Januari - Juni 2016/1438 | 43 
Rasulullah. Jika seluruh umat menjalankan prinsip perekonomian yang dilakukan oleh Rasulullah, maka tiada ada kemiskinan yang berantai.

\section{E. Analisis CSR Terhadap Pemberdayaan Masyarakat Pada Bank Konvensional}

Bank sebagai lembaga intermediasi, memiliki fungsi sebagai perantara keuangan. Dalam peranannya tersebut, terdapat hubungan antara bank dan masyarakat didasarkan pada dua unsur yang saling terkait, yaitu hukum dan kepercayaan. ${ }^{103}$ Disamping fungsi keuangan/ekonomi, bank memiliki fungsi lainnya yaitu berperan serta dalam kehidupan sosial kemasyarakatan, dan berperan pula dalam menciptakan lingkungan masyarakat yang kondusif.

Bank dalam kegiatan operasionalnya, dituntut untuk melaksanakan tanggung jawab sosialnya, sebagai wujud ikut melaksanakan kebijakan pemerintah yang termaktub dalam UndangUndang Tahun No. 40 Tahun 2007, bahwa perusahaan wajib melaksanakan kewajiban sosialnya yaitu CSR. ${ }^{104}$

Kecenderungan dari banyak perusahaan masih memaknai program corporate social responsibility hanya sebatas kegiatan donasi kepada masyarakat, masih belum dimaknai sebagai sebuah upaya serius dari perusahaan yang ditujukan untuk lebih memberdayakan masyarakat.

Masyarakat dalam program CSR, dianggap sebagai subjek paling dekat dengan dampak yang dihasilkan oleh aktivitas perusahaan, oleh karenanya permasalahan sosial masyarakat notabene diunggulkan oleh berbagai perusahaan dalam mengimplementasikan program-programnya.CSR adalah jiwa perusahaan untuk mencapai tujuan-tujuan bisnis yang mencakup citra perusahaan, promosi, meningkatkan penjualan, membangun percaya diri, loyalitas karyawan, serta keunt ungan. ${ }^{05}$

Kepedulian bank didalam tanggung jawab sosialnya/CSR didasari oleh tiga prinsip dasar yang dikenal dengan Triple Bottom Line, meliputi ekonomi (profit), sosial (people) dan lingkungan

${ }^{103}$ Johannes Ibrahim, Cross Default \& Cross Collateral Sebagai Upaya Penyelesaian Kredit Bermasalah, (Bandung :Refika Aditama, 2004), 1.

${ }^{104}$ Undang-Undang No.40 Tahun 2007 Tentang Perseroan Terbatas.

${ }^{105}$ Poerwanto, Corporate Social Responsibility (Menjinakkan Gejolak Sosial di Era Pornografi) (Jember: Pustaka Pelajar, 2010), 21.

44 I INDO-ISLAMIKA, Volume 6 No.1 Januari - Juni 2016/1438 
(planet) ${ }^{106}$ sebagaimana yang telah dikemukakan pada bab sebelumnya.Ketiganya harus berjalan sinergis dan berkesinambungan agar tercipta iklim perusahaan yang baik, sehingga eksistensi perusahaan terjamin dengan citra atau reputasi positif yang diperoleh dari konsumen dan masyarakat.

CSR dalam bidang ekonomi, mencakup kegiatan-kegiatan yang berdampak pada peningkatan peluang kerja dan peluang usaha, peningkatan pendapatan dan penurunan kemiskinan di masyarakat. ${ }^{107}$ Program ini diharapkan untuk mampu membantu masyarakat dalam meningkatkan kehidupan ekonomi mereka, melalui berbagai program yang diberikan oleh bank konvensional.

CSR dalam bidang sosial, merupakan hal yang sangat erat kaitannya dengan program-program CSR perusahaan. Masyarakat penerima manfaat dilihat sebagai subyek yang paling dekat dengan dampak yang dihasilkan oleh aktivitas perusahaan, oleh karenanya permasalahan sosial mendapat perhatian khusus oleh berbagai perusahaan dalam mengimplementasikan program-program CSR.

Bentuk kegiatan CSR bidang sosial, mencakup kegiatankegiatan sosial yang terkait dengan peristiwa yang terjadi seperti bencana alam, kebakaran, kebanjiran dan lainnya. Bentuk kegiatannya adalah dengan pemberian bantuan biaya hidup ataupun bantuan dalam bentuk lainnya.

CSR dalam bidang lingkungan, mencakup kegiatan-kegiatan yang berdampak pada peningkatan kenyamanan dan kelestarian lingkungan. Dengan adanya CSR, diharapkan perusahaan mampu memberikan upaya optimalnya dalam memenuhi tanggung jawab pada lingkungan. Program CSR yang dijalankan oleh perusahaan juga harus mampu memberikan cara yang solusif sehingga lingkungan dapat merasakan dampak positif dari program-program CSR. Idealnya upaya tanggung jawab akibat aktivitas perusahaan harus masuk kedalam agenda wajib bagi perusahaan, namun seringkali ditemukan program CSR bidang lingkungan yang masih mengikutsertakan

${ }^{106}$ Jhon Elkington, Cannibals with Forks: The Triple Bottom Line in 21st Century Business ( United Kingdom: Capstone Publishing Limited,1999), 20.

${ }^{107}$ http://www.btn.co.id/id/content/CSR/CSR/Kegiatan-CSR---PKBL-tahun2008 (Diakses, 5 Desember 2015)

INDO-ISLAMIKA, Volume 6 No.1 Januari - Juni 2016/1438 I 45 
penanggulangan kerusakan lingkungan akibat aktivitas perusahaan tersebut ke program CSR. ${ }^{108}$

Dalam penelitian ini, untuk menguji dampak CSR Bank Konvensional terhadap pemberdayaan masyarakat, maka digunakan analisisi regresi linier berganda (multiple linear regression). ${ }^{109}$ Analisis regresi linier berganda digunakan dalam penelitian ini dengan tujuan untuk membuktikan hipotesis mengenai pengaruh variabel -variabel CSR seperti variabel ekonomi, variabel sosial dan variabel lingkungan. Pengujiannya diukur secara parsial maupun secara simultan terhadap pemberdayaan masyarakat.

Perhitungan statistik dalam analisis regresi linier berganda yang digunakan dalam penelitian ini adalah dengan menggunakan bantuan sofware SPSS versi 16.0.Namun sebelum menggunakan hasil analisis regresi berganda di dalam penelitian, terdapat beberapa asumsi dasar yang harus dipenuhi terlebih dahulu.Asumsi-asumsi tersebut dinamakan uji asumsi klasik.

Dalam penelitian ini akan dilakukan tiga uji asumsi klasik, yaitu uji normalitas, uji multikolinearitas dan uji heteroskedastisitas data. Model regresi penelitian dengan variabel independentnya yaitu aspek ekonomi (X1), sosial (X2) dan lingkungan (X3). Variabel dependentnya, yaitu pemberdayaan masyarakat (Y).

Berdasarkan hasil uji regresi dapat diketahui bahwa CSR yang terdiri dari variabel ekonomi $\left(\mathrm{X}_{1}\right)$,variabel sosial $\left(\mathrm{X}_{2}\right)$ dan variabel lingkungan $\left(\mathrm{X}_{3}\right)$, memiliki pengaruh/dampak terhadap pemberdayaan masyarakat.Sebagaimana disajikan dalan tabel 4.16 yang menggambarkan uji $\mathrm{F}$ memperlihatkan ketiga variabel independen tersebut secara bersama-sama (simultan) mempunyai dampak signifikan terhadap pemberdayaan masyarakat.

${ }^{108}$ Intan Kirana, Peran CSR Bidang Lingkungan Dalam Menunjang Perolehan Progran Penilaian Peringkt Kinerja Perusahaan (Proper) PT Surya Kertas,Jurnal Ilmiah Mahasiswa USU Vol.2(2) 2009:1-15 http://Journal.ubaya.ac.id/index.php/jimus/article/view/329/320 (Diakses 2 Januari 2016)

${ }^{109}$ Analisa regresi linier berganda adalah suatu teknik yang digunakan untuk membangun suatu persamaan yang menghubungkan antara variabel tidak bebas (dependent variable $=\mathrm{Y}$ ) dengan beberapa variabel bebas (independent variabel $=\mathrm{X}$ ). Tujuan analisis regresi berganda adalah untuk memperkirakan perubahan respons pada variabel terikat terhadap beberapa variabel bebas. (Suharyadi,Poerwanto S.K, Statistika untuk Ekonomi dan Keuangan Modern ( Jakarta: Salemba Empat, 2004), 469.

46 I INDO-ISLAMIKA, Volume 6 No.1 Januari - Juni 2016/1438 
Tabel 5.16 Hasil Uji F

ANOVA $^{\mathrm{b}}$

\begin{tabular}{|rl|r|r|r|r|r|}
\hline & Model & \multicolumn{1}{c|}{$\begin{array}{c}\text { Sum of } \\
\text { Squares }\end{array}$} & \multicolumn{1}{c|}{ df } & \multicolumn{1}{c|}{$\begin{array}{c}\text { Mean } \\
\text { Square }\end{array}$} & \multicolumn{1}{c|}{ F } & \multicolumn{1}{c|}{ Sig. } \\
\hline 1 & Regression & 19.607 & 3 & 6.536 & 39.008 & $.000^{\mathrm{a}}$ \\
& Residual & 11.058 & 66 & .168 & & \\
& Total & 30.665 & 69 & & & \\
\hline
\end{tabular}

a.Predictors: (Constant), Aspek Lingkungan, Aspek Ekonomi, Aspek Sosial

b.Dependent Variable: Pemberdayaan Masyarakat

Tabel 5.16 hasil Uji $\mathrm{F}$ menunjukkan bahwa nilai probabilitas sig sebesar 0,00 di mana nilai tersebut lebih kecil dari alpha sebesar 0,05 atau $(\alpha=5 \%)$, sehingga dapat disimpulkan bahwa ada pengaruh/dampak CSR Bank Konvensional secara simultan terhadap pemberdayaan masyarakat. Hasil uji secara parsial (t uji), dari tiga variabel ekonomi, sosial dan lingkungan, hanya variabel ekonomi yang tidak memiliki dampak signifikan, sedangkan variabel sosial dan lingkungan memiliki dampak terhadap pemberdayaan masyarakat. Untuk lebih terperinci masing-masing variabel akan dibahas pada sub bab tersendiri.

Hasil penelitian tersebut sejalan dengan teori yang dibangun oleh Jim Ife, mengatakan bahwa dalam pemberdayaan masyarakat, interaksi aspek sosial, ekonomi, politik, budaya, lingkungan dan spiritual tidak semuanya akan setara. Tetapi disesuaikan dengan situasi, kondisi dan level masyarakat serta perlu adanya skala prioritas dalam pemberdayaan masyarakat. ${ }^{110}$

Budaya atau adat istiadat masyarakat penerima manfaat, sangat berpengaruh terhadap pola pikir masyarakat. Demikian juga kondisi politik suatu negara akan berpengaruh dalam kehidupan masyarakat. Situasi politik yang tidak stabil secara makro akan mempengaruhi kehidupan masyarakat. Kebijakan perekonomian yang

${ }^{110}$ Jim Ife \& Frank Tesoriero, “Community Development : Creating Communty Alternatives, Vision, Analysis and Practice ( Australia: Longman,1995), 56. 
tidak berpihak kepada masyarakat kecil. Pembangunan yang tidak merata, akan menimbulkan ketimpangan-ketimpangan atau kesenjangan dalam kehidupan masyarakat.

Demikian pula dari hasil perhitungan regresi dapat diketahui bahwa koefisien determinasi (Adjusted $R$ Square) yang diperoleh sebesar 0,623 . Hal ini berarti 62,3 persen pemberdayaan masyarakat dipengaruhi oleh ekonomi, sosial dan lingkungan, sedangkan sisanya yaitu sebesar $(100 \%-62,3 \%)=37,7 \%$. Artinya bahwa 37,7\% dapat dipengaruhi oleh variabel-variabel atau faktor-faktor lain yang tidak dijelaskan dalam penelitian ini sebagaimana disajikan dalam tabel 5.17 dibawah ini.

\section{Tabel 5.17 Koefisien Determinasi}

Model Summary ${ }^{\mathrm{b}}$

\begin{tabular}{|l|r|r|r|r|r|}
\hline Model & R & R Square & $\begin{array}{c}\text { Adjusted R } \\
\text { Square }\end{array}$ & $\begin{array}{c}\text { Std. Error of } \\
\text { the Estimate }\end{array}$ & $\begin{array}{l}\text { Durbin- } \\
\text { Watson }\end{array}$ \\
\hline 1 & $.800^{\mathrm{a}}$ & .639 & .623 & .40932 & 2.178 \\
\hline
\end{tabular}

a. Predictors: (Constant), Bidang Lingkungan, Bidang Ekonomi, Bidang Sosial

b. Dependent Variable: Pemberdayaan Masyarakat

Pemberdayaan ekonomi masyarakat penerima manfaat adalah usaha untuk menjadikan ekonomi yang kuat, besar, modern, dan berdaya saing tinggi dalam mekanisme pasar yang benar.Pemberdayaan ekonomi tidak cukup hanya dengan peningkatan pendapatan atau penghasilan, memberikan kesempatan berusaha yang sama, kesempatan untuk memperoleh lapangan pekerjaan dan hanya memberikan suntikan modal sebagai stumulan, tetapi harus dijamin adanya kerjasama dan kemitraan yang erat antara yang telah maju dengan yang masih lemah dan belum berkembang. ${ }^{111}$

${ }^{111}$ Gunawan Sumodiningrat, Pemberdayaan Masyarakat dan Jaring Pengaman Sosial (Jakarta :Gramedia; 1999 ), dikutif dalam Mardi Yatmo Hutomo, Pemberdayaan Masyarakat dalam Bidang Ekonomi: Tinjauan Teoritik danImplementasi.

http://www.bappenas.go.id/files/2913/5022/6062/mardi 20091015151035 2384 0.pdf (Diakses, 3 Desember 2015).

48 I INDO-ISLAMIKA, Volume 6 No.1 Januari - Juni 2016/1438 
Pemberdayaan sosial masyarakat penerima manfaat, dapat dilihat bagaimana usaha rumah tangga lemah memperoleh akses informasi, akses pengetahuan dan ketrampilan, akses untuk berpartisipasi dalam organisasi sosial, dan akses ke sumber-sumber keuangan. ${ }^{112}$

Pemberdayaan lingkungan masyarakat, Upaya peningkatan kualitas lingkungan umumnya dilakukan oleh masyarakat, kecuali lingkungan permukiman kumuh yang penanganannya dilakukan oleh pemerintah maupun swasta. Peningkatan kualitas lingkungan yang dilakukan masyarakat perkotaan maupun perdesaan sangat bervariasi sesuai dengan kondisi sosial, ekonomi dan budayanya. ${ }^{113}$

Secara konseptual, pemberdayaan masyarakat adalah upaya untuk meningkatkan harkat dan martabat lapisan masyarakat yang dalam kondisi sekarang tidak mampu untuk melepaskan diri dari perangkap kemiskinan dan keterbelakangan. Dengan kata lain pekerjaan memberdayakan adalah memampukan serta memandirikan masyarakat. ${ }^{114}$

\section{F. Kesimpulan}

Penelitian ini membuktikan, bahwa terdapat perbedaan dampak Corporate Social Responsibility terhadap pemberdayaan masyarakat pada bank syariah dan bank konvensional. Berdasarkan hasil pengukuran secara terpisah, CSR bank syariah dan bank konvensional dalam pemberdayaan masyarakat dengan menggunakan tiga variabel yaitu aspek ekonomi, sosial dan lingkungan, maka aspek ekonomi pada bank konvensional tidak memiliki dampak terhadap pembedayaan masyarakat, sedangkan bank syariah memiliki dampak pada pemberdayaan ekonomi masyarakat.

Program CSR bank konvensional mengindikasikan tidak murni berperan dalam pemberdayaan ekonomi masyarakat, tapi lebih kearah bisnis komersil dan keberpihakan kepada pelaku usaha yang lebih

\footnotetext{
${ }^{112}$ Friedman, Empowement: the Politics of Alternative Development. CambridgeMass:BlackwellPublisher.1992. http://www.bappenas.go.id/files/2913/5022/6062/mardi200910151510352384__o.pdf

${ }^{113}$ I ketut Alit, "Pemberdayaan Masyarakat dalam Peningkatan Kualitas Lingkungan Permukiman Kumuh di Propinsi Bali," Jurnal Permukiman Natah VOL. 3 NO.1( Februari 2005), 1 - 61.

${ }^{114} \mathrm{https}: / /$ www.scribd.com/doc/76409169/Contoh-Kasus-PemberdayaanMasyarakat (Diakses, 10 Desember 2015).
}

INDO-ISLAMIKA, Volume 6 No.1 Januari - Juni 2016/1438 | 49 
feasible. Program CSR yang dilakukannya yaitu dengan model PKBL yaitu Program Kemitraan dan Bina Lingkungan. Sebenarnya Program Kemitraan sesuai dengan visi dan misinya yang mempunyai tujuan yang sangat mulia, yaitu meningkatkan kompetensi usaha kecil agar menjadi tangguh dan mandiri melalui pemanfaatan dana bagian laba dari perusahaan, dengan pola pembinaan dan pendampingan, tapi sayang program tersebut berujung pada fasilitas pinjaman dengan suku bunga dan persyaratan yang memberatkan masyarakat. Fasilitas pinjaman Program Kemitraan tersebut setelah memastikan terlebih dahulu bahwa dana yang mereka pinjamkan jatuh ke tangan orang yang sudah biasa berbisnis. Bank tidak akan mempercayakan uangnya jatuh kepada orang-orang yang tidak mempunyai pengalaman berbisnis.Hal ini, membuktikan bank konvensional dalam program CSR, tetap berorientasi pada profit motive. Karena tidak memberikan fasilitas pinjaman kepada wirausaha pemula.

CSR Bank Syariah melaksanakan program-program pemberdayaan ekonomi dan sosial masyarakat secara terintegral dan komprehensif, membangun dan mengembangkan jaringan kerja pemberdayaan seluas-luasnya. Bank syariah dalam mengelola dana CSR, bekerjasama dengan Lembaga Swadaya Masyarakat/LSM, seperti Lembaga Dompet Dhuafa. Mendirikan Baital-Māl wat Tamwil/BMT, dan KJKS ( Koperasi Jasa Keuangan Syariah). Program ini dilakukan melalui penyaluran produk kredit kebajikan (qard alhasan), yaitu pinjaman tanpa margin (bagi hasil) atau tanpa bunga kepada masyarakat sebagai pelaku usaha kecil dan menengah (UKM). Dana fasilitas ini diperoleh dari denda, pendapatan non halal, zakat, infaq, sedekah dan wakaf (Ziswaf) karyawan, nasabah dan masyarakat umum, serta dana sosial lainnya. Bentuk program yang dilaksanakannya, melalui pendampingan usaha, pelatihan kewirausahaan dan membina mereka agar mencapai kemandirian usaha.

Sebaliknya bank konvensional lebih memberdayakan lingkungan sosial kemasyarakatan dari pada bank syariah. Hal ini mengindikasikan bank syariah belum mengimplementasikan visi dan misi tujuan sosial dan belum mencerminkan ajaran Islam dalam wujud operasional praktis yang dapat dipraktekkan pada perbankan syariah.

Bank syariah maupun bank konvensional, secara normatif penyelenggaraan program CSR, didorong oleh kesadaran untuk bertanggung jawab secara sosial.Tetapi, sebagian besar CSR yang 
dilaksanakan masih bersifat karikatif. Pada umumnya kepentingan untuk membentuk corporate image dan citra positif perusahaan melalui bantuan terasa lebih menonjol. Bantuan atau sumbangan (charity) yang diberikan masih ditujukan untuk kebutuhan sesaat, belum memikirkan aspek keberlanjutan pembangunan (sustainability development) dan pemberdayaan masyarakat (social empowerment) secara optimal. Disamping itu, juga perusahaan melaksanakan CSR, hanya sekedar menjalankan peraturan pemerintah, agar gugur kewajibannya.

Disertasi ini memiliki persamaan dengan penelitian yang dilakukan oleh Sayd Farook, et al (2011), Al-Qadi (2012), Yazis, et al (2013), Chintaman (2014), dan Ershad Ali (2015), bahwa bank syariah menerapkan tanggung jawab sosial dalam semua aspek, sedangkan bank konvensional lebih pada aspek sosial dan lingkungan.

Dalam tatanan teoritis, disertasi ini sependapat dengan teori yang dikemukakan oleh Elkington (1999), Chahal, et al (2006), David Crawther (2008), bahwa dalam pemberdayaan masyarakat hendaklah disertai transformasi secara seimbang, yaitu transformasi ekonomi, sosial, lingkungan, budaya, agama maupun politik sehingga akan terjadi keseimbangan antara kekuatan ekonomi, kekuatan sosial, kekuatan lingkungan, politik, budaya dan agama. Kekuatan faktorfaktor itu akan membentuk kemandirian masyarakat.

Disertasi ini tidak sependapat dengan, yaitu teori yang dikemukakan oleh Milton (1962), Bakan (1970) dan Thurow (1997), bahwa tanggung jawab sosial perusahaan hanyalah memaksimumkan profit. Tanggung jawab sosial hanya ada pada individu dan tidak melekat pada perusahaan.Sebab tanggung jawab perusahaan adalah menghasilkan keuntungan sebesar-besarnya bagi pemegang saham.

\section{DAFTAR PUSTAKA}

Accounting and Auditing Organization for Islamic Financial Institution /AAOIFI, Accounting and Auditing and Governance Standard for Islamic Financial Institutions. Manama Bahrain: AAOIFI, 1999.

Adiningsih, Sri. Koordinasi dan Interaksi Kebijakan Fiskal-Moneter: Tantangan ke Depan, Yogyakarta: Kanisius, 2012. 
Badri, Arifin, Muhammad, dkk, Bersihkan Riba di Bank Syariah, Majalah Pengusaha Muslim, Yayasan Bina Pengusaha Muslim, 1 Maret 2012.

Bakan, Joel.Tj, The Corporation, Pengejaran Patologis Terhadap Harta danTahta. Jakarta: Penerbit Erlangga, 2007.

C.Thurow, Lester, The Future of Capitalism, How to Day Economic Forces Shape, Tomorrow's Word,Nicholas Braeley, 1997.

Carrol, Archie B. "A History of Corporate Social Responsibility: Concept and Practice". DalamThe Oxford Handbook of Corporate Social Responsibility, Great Britain: Oxford University Press, 2008.

Esben, Pedersen \&Neegard, Peter, Managing Corporate Social Responsibility In Action. Ashgate Publishing Limited : England, 2007.

Esposito, Jhon L. "Fatwa," The Oxpord Encyclopedia of The Modern Islamic Word, New York : Oxport University Press, 1990.

Friedman, Bill, Empowerment : The Politics Alternatif Development, Cambridge Mass:Blacwell Publishers ,1992.

Friedman, Milton, Capitalism and Freedom, Chicago: The University of Chicago Press: 1962.

Ghazaly, Al, Abdul Muqsith. Maqāsid Sharī'ah. Dalam Ekonomi dan Keuangan Shari' 'ah. Jakarta, tp, 2013.

Ibrahim, Abu Ishaq bin Musa al-Lakhmi al-Gharnathi al-Syatibi, Al Muwafaqat Fi Ushul al-Ahkam,jilid II,Dar al-Fikr, Beirut,tt.

Ife,Jim ,Community Development :Creating Communty Alternatives Vision, Analysis and Practice, Australia-Sydney:Longman, 1995.

John, Fulton, The Future of Capitalism, How to Day Economic Forces Shape, Tomorrow's Word, Nicholas Braeley, 199.

Khan, Mohammad Akram, An Introduction to Islamic Economics, Virginia: International Institute of Islamic Thought Khan 1994.

Kotler, Philip. and Nancy Lee. Corporate Social Responsibility: Doing the Most Good for Your Company and Your Cause. Hoboken. New Jersey: John Wiley and Sons, Inc,2005

Latief, Hilman, Melayani Umat Filantropi Islam dan Ideologi Kesejahteraan Kaum Modernis Jakarta : Gramedia Pustaka Utama, 2010.

Muflih Saefuddin, Ahmad Perbandingan Sistem Ekonomi Islam dengan Kapitalisme dan Marxisme, Wawasan Islam dan 
Ekonomi, Sebuah Bunga Rampai, Jakarta:Lembaga Penerbit FE UI, 1997.

Muhammad, Bank Syariah, Analisis Kekuatan, Kelemahan, Peluang dan Ancaman, Yogyakarta :Ekosinia, 2003.

Prijono, Onny, Pemberdayaan, Konsep, Kebijakan \& Implementasi, Jakarta:CSIS, 1996

Rahman, Reza, Corporate Social Responsibility Antara Teori dan Kenyataan, Yogyakarta: Media Pressindo, 2009.

Rand, Ayn, Capitalism, the Unknown Ideal, New York: A.Signet Book, 1970

Slamet, M,Pemberdayaan Masyarakat. Dalam Membetuk Pola Perilaku Manusia Pembangunan. Disunting oleh Ida Yustina dan Adjat Sudradjat. Bogor: IPB Press, 2003.

Solihin, Ismail, Corporate Social Responsibility From Charity to Sustainability, Jakarta: PT. Riau Andalan Pulp and Paper, 2008.

Thanthawy, Muhammad Sayyid, Mu'āmalah al-Bunūk wa Ahkamuha al-Syar'iyyah, Mishr: Dār al-Nahdhah,1997.

Thurow ,Lester C; The Future of Capitalism, How to Day Economic Forces Shape

Trisoko S, Definisi CSR, breath4justice, www.csrindonesia.com(diakses 7 Oktober 2014)

W. Robinson, Kennes, Community Development in Perspective, Iowa State : University Press , 1989.

Wandersman, Abraham, et al, The Principle of Empowerment Evaluation,Empowerment Evaluation: Principles in Practice, New York: The Gulford Press.2005.

\section{JURNAL}

Achda, B. Tamam, Konteks Sosiologis Perkembangan Corporate Social Responsibility (CSR) dan Implementasinya di Indonesia.\| (Makalah). Seminar Nasional: A Promise of Gold Rating: Sustainable CSR, Jakarta, 23 Agustus 2006.

Ali, Ershad \& S. M. Mahbubur Rahman, "Corporate Social Responsibility Disclosure: A Comparative Study Between Islamic Banks and Conventional Banks in Bangladesh, CSCanada", International Business and Management, Vol. 10, No. 1 (2015): 9-17. 
Sufyati HS

Bank Mandiri," Laporan Good Corporate Governance PT Bank Mandiri Tbk ,"Bank Mandiri (2014):606-624.

Bank Muamalat, "Laporan Good Corporate Governance PT Bank Muamalat Indonesia Tbk", Bank Muamalat (2014): 24-130.

Benedict Sheehy, Scrooge -The Reluctant Stakeholders: Theoretical Problems In The Shareholder-Stakeholders Debate",University of Miami Business Law Review 14 (Fall/Winter, 2005): 197

Boulouta, Ioanna and Christos N. Pitelis, "Who Needs CSR? The Impact of Corporate Social Responsibility on National Competitiveness, Journal of Business Ethics, Vol. 119, No. 3 (February 2014), pp. 349-364.

Carrol, Archie, "A Three-Dimensional Conceptual Model of Corporate Social Performance." Academy of Management Review, Vol. 4 , No. 4, (1979): 497-505.

Carroll, Archie, Corporate Social Responsibility, Evolution of a Definitional Construct," Business and Society, Vol. 38/3, (1999).

Chintaman, S.A, A Comparative Study of CSR Practices of Islamic Banks and Conventional Banks in GCC Region", Journal of Islamic Banking and Finance Vol. 2, No. 1,(March 2014),1-21. Department of Commerce and Accountancy, Shri H. K. Commerce College, Gujarat University, India.

Cowen, S.S., Ferreri, L.B., dan L.D. Parker. 1987. "The Impact of Corporate Characteristics On Social Responsibility Disclosure: A Typology and Frequency-Based Analysis". Accounting, Organisationsadn Society. Vol. 12 No. 2, pp. 111-122.

Emma García-Meca, et al" Board Diversity and Its Effects on Bank Performance: An International Analysis, Journal of Banking \& FinanceVolume 53, April 2015, Pages 202-214.

Erol, C., E. Kaynak, and R. El-Bdour "Conventional and Islamic Bank: Patronage Behaviour of Jordanian Customers, International Journal of Bank Marketing,1990,8(5), 25-35.

Fetterman, David and Wandersman, Abraham, "Empowerment Evaluation:Yesterday, Today, and Tomorrow ", American Journal of Evaluation 2007.

Friedman, Milton," The Social Responsibility of Business is to Increase itsProfits" dalamThe New York Times Magazine (September 13, 1970) 214. 
Habztop, Perkembangan dan pentingnya Corporate Social Responsibility, http://images.habztop.multiply.multiplycontent.com/attachmen t/0/Ro5OOQoKCsMAAEo6S5I1/Beberapa\%20tahun\%20terak hir\%20ini.doc?nmid=48783 225. Diakses.10 Juni 2014.

Hamdi Khalfaoui.et al. "The Determinants of Banking Performance Empirical Evidence from Tunisian Listed Banks "International Journal of Finance \& Banking StudiesIJFBS ISSN: 2147-4486 Vol.4 No.2, 2015. www.ssbfnet.com/ojs

Inten, Mutia, Shariah Enterprise Theory sebagai Dasar Pengungkapan Tanggung Jawab Sosial untuk Bank Syariah “, Disertasi, Program Pasca Sarjana Universitas Brawijaya Malang (2010), dalam Erwanda, Edwin dan Mulawarman, Aji, Dedi,Tanggung Jawab Sosial pada Organisasi Perbankan Syariah, Studi Kasus pada BNI Syariah Cabang Malang (2013).

Irwansyah, $M$, Putra,dkk,Peranan Otoritas Jasa Keuangan Dalam Melakukan Pengaturan dan Pengawasan Terhadap Bank, e'journal of economics law, TRANSPARENCY, Vol 2 No 1 , 2013:1-9.

Jalal," Tanggung Jawab Sosial Perusahaan di Indonesia", Koran tempo, 26 September 2006.

Jamali, Dima , Yusuf Sidani and Khalil El-Asmar A Three Country Comparative Analysis of Managerial CSR Perspectives: Insights From Lebanon, Syria and Jordan Journal of Business Ethics Vol 85, No. 2 (March 2009), pp. 173-192.

Medhat Tarawneh, "A Comparison of Financial Performance in The Banking Sector: Some Evidence from Omani Commercial Banks, International Reseacrh Journal of Financial and Economics (2006).ISSN 1450-2887.

Mele, Garga, "Corporate Social Responsibility Theories: Mapping the Territory," Journal of Business Ethics, Vol. 53, 2004).

Naim S. Al-Qadi," Social Responsibility of Islamic Banks (Jordan Case)," Finance and Banking Department, Al-Balqa Applied University Amman - Jordan, British Journal of Humanities and Social Sciences 12 June 2012, Vol. 6 (1): 12-20.

Nasution, Bismar, "Beberapa Catatan terhadap RUU Otortas Jasa Keuangan,"Buletin Hukum Perbankan dan Kebansentralan, Volume 8, Nomor 3, September 2010. 
Rima Turk Ariss, Competitive Conditions in Islamic and Conventional Banking: A Global Perspective, Review of Financial Economics Volume 19, Issue 3, August 2010, Pages 101-108.

Ronald Jeurissen, Cannibal With Forks : The Triple Bottom Line of 21 st Century Business, Journal of Business Ethics ; Jan 2000; 23,$2 ;$ pg 229.

Sayd Farook, et al , Banking on Islam? Determinants of Corporate Social Responsibility Disclosure, Ph.D. Students, School of Accounting, University of Technology, Sydney, P. O. Box 123, Broadway, NSW 2007, Australia, pages 355-388, E-mail: sayd.farookuts.edu.au.

Sinclair,P.J.N." Central Bank and financial Stability,"Bank of England Quarterly Bulletin (2000):377-391.

Tanudjaja, Perkembangan Corporate Social Responsibility di Indonesia, NIRMANA,VOL.8,NO.2 (Juli 2006):92-98.

Thorsten Beck, et al, Islamic vs. Conventional Banking: Business Model, Efficiency and Stability, Journal of Banking \& FinanceVolume 37, Issue 2, February 2013, Pages 433-447.

Wartick, S. L. and P. L. Cochran (1985), "The Evolution of the Corporate Social Performance Model", Academy of Management Review, 10(4), 758-69.

Wood, D. J. (1991), "Corporate Social Performance Revisited', Academy of Management Review, 16(4), 691-718.

Yusuf, Muhammad Yasir, "Model Pelaksanaan CSR Bank Syariah (Kajian Empiris Pembiayaan Mikro Baitul Mal, Aceh)." La_Riba, Jurnal Ekonomi Islam,Volume IV, No. 2, Desember ( 2010)

Yusuf, Muhammad Yasir,and Zakarian bin Bahari, "Islamic Corporate Social Responsibility in Islamic Banking: Towards Poverty Alleviation" 8th International Conference on Islamic Economics and Finance, Sustainable Growth and Inclusive Economic Development From an Islamic Perspective, December 19-21, 2011. 